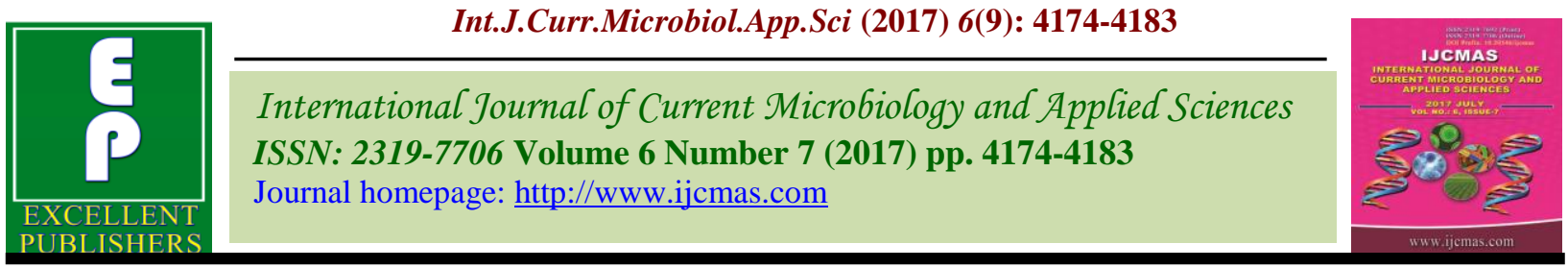

Original Research Article

https://doi.org/10.20546/ijcmas.2017.607.432

\title{
Effect of Different Crop Establishment Methods, Tillage and Residue on Yield, Yield Attributes and Economics of Ricein RW System of Northern Plains of IGP
}

\author{
J.M. Sutaliya* and U.P. Singh \\ Department of Agronomy, Institute of Agricultural Sciences, Banaras Hindu University, \\ Varanasi, Uttar Pradesh, India- 221005 \\ *Corresponding author
}

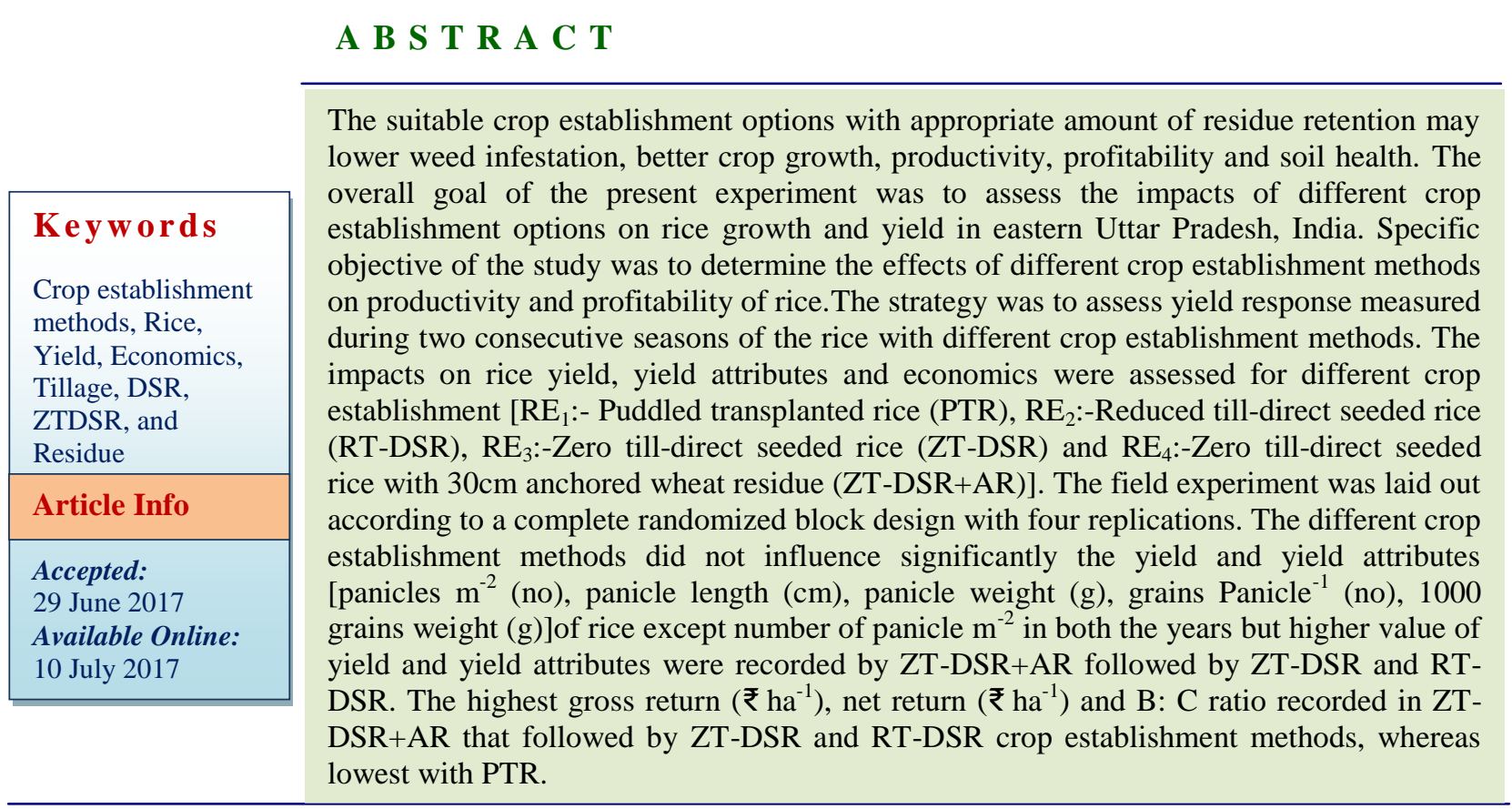

\section{Introduction}

Rice and wheat are staple food crops of the world cultivated on an area around $370.4 \mathrm{~m}$ ha. A large proportion of world population relies on rice and wheat for daily caloric intake, income and employment. Rice-wheat cropping system is one of the major cropping systems in South Asia and is practiced in 14 million hectares area (Singh et al., 2010) providing food for more than 400 million people.
The rice-wheat production systems are fundamental to employment, income, and livelihoods for hundreds of millions of rural and urban population of South Asia (Saharawat et al., 2010). This system covers about 10.5 million hectares in India contributes $26 \%$ of total cereal production, $60 \%$ of total calorie intake and about $40 \%$ of the country's total food basket (Sharma et al., 2015).In India rice occupies nearly 44.1 
million hectares area, 105.5 million tonnes total production with a productivity of 2291 $\mathrm{kg} / \mathrm{ha}$ productivity for the year 2014-15 (Anonymous, 2016). Rice is the most important staple food in Asia, where more than $90 \%$ of the world's rice is grown and consumed.

Tillage is one of the basic inputs of crop production, actually tillage alters the rhizosphere environment by modifying most of the physical properties of the soil, viz. bulk density and soil strength, hydraulic conductivity and aggregates stability, infiltration rate and porosity due to formation, destruction and rearrangement of soil particles and aggregates and alternation in clod size distribution (Guzha, 2004).In the conventional systems involving intensive tillage, there is gradual decline in soil organic matter by quicker oxidation and burning of crop residues causing pollution, greenhouse gases emission, and loss of valuable plant nutrients. However, the extent of the impacts of tillage is variable depending upon the inherent soil characteristics and climatic conditions.

Efficient management of costly input like diesel, at present having substantial subsidy, can help in reducing the cost of production, and thereby making, the produce more competitive. In conventional practice of rice growing with manual transplanting of rice seedlings in random geometry after intensive dry, wet tillage and puddling contributes significantly to these challenges, making this system unsustainable.

Puddling effects adversely on soil-physical condition for establishment and raising the succeeding crops (Tripathi et al., 2003). This practice is water, capital and energy intensive, and deteriorates soil health (Sharma et al., 2003). Puddling leads to the formation of a hard-pan at shallow depths deteriorates soil physical properties and delays planting of a succeeding wheat crop. Timely planting of wheat is crucial as yield reductions of $1-1.5 \%$ per day occur for each day after the optimum sowing date, November 15 in the IGP (Hobbs and Morris, 1996).

Retaining crop residues on the soil surface provides a source of plant nutrients, improves organic matter level in the soil and increased soil water content by reducing evaporation and increasing infiltration rate (Chastin et al., 1995). Conservation tillage systems not only reduce erosion and improve the soil environment for crop growth, but also conserve energy and decrease the labour cost of farming (Triplett and Van Doran, 1977).

Due to rising cost of labour and excessive water use in puddling for transplanting rice in the irrigated eco-systems, direct seeding of rice is gaining popularity in south-east Asia (Balasubramanian and Hill, 2002). Directseeded rice needs only $34 \%$ of the total labour requirement and saves $29 \%$ of total cost of the transplanted crop (Ho and Romli, 2002). Important factors that are forcing a shift from the traditional puddled-transplanting system to unpuddled direct seeding of rice are shortages of labour and water, and escalating fuel prices.

Resource-conserving technologies (RCTs) such as zero-tillage (ZT) and un-puddled transplanting have been shown to be beneficial in terms of improving soil health, water use, crop productivity and farmers' income (Gupta and Sayre, 2007; Singh et al., 2009).

The present experiment was conducted to determine suitable crop establishment options with appropriate amount of residue retention may lower weed infestation; improve crop growth, productivity, profitability and soil health in rice wheat cropping system. 


\section{Materials and Methods}

\section{Experimental site}

A field experiment was conducted during kharif season of 2011 and 2012 at the Agricultural Research Farm, Institute of Agricultural Sciences, Banaras Hindu University (BHU), Varanasi, Uttar Pradesh, India. The experimental site is located in the south-eastern part of the Varanasi. The geographical location of the farm lies at $25^{\circ} 18^{\prime} \mathrm{N}$ latitude and $88^{\circ} 36^{\prime} \mathrm{E}$ longitude at an altitude of 128.93 meters above the mean sea level in the Northern Gangetic alluvial plains.

\section{Crop and climate}

The climate of experimental site is typically semi-arid to sub-humid, characterized by extremes of temperatures both in summer and winter with low rainfall and moderate humidity. The normal period for the onset of monsoons in this region is the third week of June and it lasts up to the end of September or sometimes extends to the first week of October. Winter showers are often experienced between December and midFebruary. However, a dry spell of three months occurs from March to May. Long term average (over 1980 to 2015) of annual rainfall for this region amounts to $1081.5 \mathrm{~mm}$, out of which $944.5 \mathrm{~mm}$ (87.33 per cent) is received during the monsoon or rainy season (June to September) and $137.0 \mathrm{~mm}$ (12.67 per cent) during post monsoon season or post rainy season. The winter months (with the temperature of $9.3^{\circ} \mathrm{C}$ ) are cool whereas summers are hot $\left(39^{\circ} \mathrm{C}\right)$ and dry. The coldest and hottest months are first half of January and May, respectively. The temperature begins to rise in February and reaches the maximum in May. The maximum temperature usually fluctuates between $22^{\circ} \mathrm{C}$ and $40.7^{\circ} \mathrm{C}$ while minimum temperature varies from 8.6 to $29.9^{\circ} \mathrm{C}$ occasionally extreme of minimum and maximum temperature variations are realized (Table 1).

\section{Soil analysis}

In order to assess the physio-chemical properties, soil samples were taken from surface soil $(0-15 \mathrm{~cm})$ before conducting the experiment considering all possible precautions prescribed for soil sampling (Black et al., 1965). For soil sampling, each plot was divided into four grids. Within each grid cell, soil was collected from four spots and. The soil samples were air-dried in the shade, grinded and passed through a $2 \mathrm{~mm}$ sieve. Bulk Density (BD) was measured by core sampler methods and textural class was determined by Robinson's International pipette method (Piper, 1966). Soil pH and electrical conductivity (EC) was determined in the saturation extract of 1: 2 (soil: water suspension) solution as described by Jackson (1973). Soil organic carbon was analyzed using Walkley and Black's (1934) rapid titration method. Available $\mathrm{P}$ in 0.5 $M \mathrm{NaHCO}_{3}$ extracts by Olsen et al., (1954) method and exchangeable $\mathrm{K}$ in $\mathrm{I} M \mathrm{NH}_{4} \mathrm{OAc}$ extracts by flame photometer method (Jackson, 1973).The experimental soils were silty loam in texture and low in nitrogen and medium in available phosphorus and potassium. The initial soil characteristics of the experimental sites are given in Table 2.

\section{Treatment details and field layout}

The field experiment was laid out according to a complete randomized block design with four replications. The experiment comprised of 4 treatment combinations consisting four methods of crop establishment $\left[\mathrm{RE}_{1}\right.$ :- Puddled transplanted rice (PTR), $\mathrm{RE}_{2}$ :-Reduced tilldirect seeded rice (RT-DSR), $\mathrm{RE}_{3}$ :-Zero tilldirect seeded rice (ZT-DSR) and $\mathrm{RE}_{4}$ :-Zero till-direct seeded rice with $30 \mathrm{~cm}$ anchored wheat residue (ZT-DSR+AR)]. The gross and 
net plot size was $22 \times 4 \mathrm{~m}, 21 \times 3.26 \mathrm{~m}$, respectively. The distance between the Main irrigation channel cum replication border and plot border were $1 \mathrm{~m}$ and $0.5 \mathrm{~m}$ on both sides.

\section{Variety}

The variety Sarjoo 52 (FH-132) which has been released in year 1980 was bred from tall and dwarf cross (TN1 $x$ Kashi) in the Department of Genetics and Plant breeding at N.D.U.A.T., Kumarganj, Faizabad (U.P.). It is an Indica $x$ Indica hybrid synthesized from parent T136 short duration tall Indica with slender grain and a Russian strain 2652. Sarjoo 52 is of dwarf statured $(82-87 \mathrm{~cm})$, stiff grain, non-lodging, moderate tillering (914), medium broad leaves with delayed senescence leaf sheath and dull straw colour. It matures in 130-135 days and is moderately resistant to BLB, Brown leaf spot and blast. It is recommended for eastern U.P. under irrigated condition for early planting. Its grain size is long and bold. Yield varies from 50-60 q ha ${ }^{-1}$.

\section{Cultural practices and observations}

A uniform dose of $120 \mathrm{~kg} \mathrm{~N}, 60 \mathrm{~kg} \mathrm{P}_{2} \mathrm{O}_{5}, 60$ $\mathrm{kg} \mathrm{K} \mathrm{K}_{2} \mathrm{O}$ and $5 \mathrm{~kg} \mathrm{Zn} \mathrm{ha}^{-1}$ was applied for rice crop in all the treatments through urea (46\% $\mathrm{N})$, DAP $\left(18 \% \mathrm{~N} \& 46 \% \mathrm{P}_{2} \mathrm{O}_{5}\right)$, muriate of potash $\left(60 \% \mathrm{~K}_{2} \mathrm{O}\right)$ and $\mathrm{ZnSO}_{4}$ respectively. Half of total nitrogen and full dose of $\mathrm{P}_{2} \mathrm{O}_{5}$, $\mathrm{K}_{2} \mathrm{O}$ and $\mathrm{Zn}$ were applied to rice crop as basal (sowing/transplanting) and remaining half dose of nitrogen in the form of urea was top dressed in two equal splits, at active tillering and panicle initiation stage during both the years, respectively. In RTDSR and ZT rice treatments sowing was done by tractor drawn zero-till seed-cum-fertilizer drill with a row spacing of $18.5 \mathrm{~cm}$ apart and seeding depth was maintained at $2-3 \mathrm{~cm}$ using depth control wheel of the planter. Rice variety "Sarjoo 52" was used at the rate of $25 \mathrm{~kg} \mathrm{ha}^{-1}$. Seeding was done on $24^{\text {th }}$ June during 2011 and $23^{\text {th }}$ June during 2012 in RTDSR and ZT Rice treatments. On the same day seeds were sown in nursery for conventional till rice (puddled transplanted) and 20 day old seedlings were manually transplanted randomly (farmers practice) in both the years. The herbicide glyphosate $\left(1 \mathrm{~kg} \mathrm{ha}^{-1}\right)$ was applied in zero-till treatments before the seeding to knock down the weeds, pendimethalin $1 \mathrm{~kg} \mathrm{ha}^{-1}$ (preemergent) $f b$ bispyribac $25 \mathrm{~g} \mathrm{ha}^{-1}$ at 20 DAS/DAT were appliedby using knap sack sprayer with flat fan nozzle for weed control. The crop was harvested at maturity stage. First, the border rows were harvested and separated. Later, crop from net plot was harvested and sun dried. The harvested material from each net plot was carefully bundled, tagged and brought to the threshing floor separately. Threshing was done plotwise and grains were cleaned, dried and weighed separately for each net plot and computed in terms of $\mathrm{kg} \mathrm{ha}^{-1}$ at $14 \%$ moisture level. The straw yield was also recorded plot wise after sun drying and computed to $\mathrm{kg}$ ha ${ }^{1}$.Test weight (g) of 1000-seeds from each plot was recorded. The economics are calculated viz. Gross and return (₹ $\mathrm{ha}^{-1}$ ) and B: $C$ ratio separately.

\section{Statistical analysis}

The data recorded for different crop parameters were analyzed using analysis of variance (ANOVA) technique (Gomez and Gomez, 1984) for complete randomized block design. Where ANOVA was significant, the treatment means were compared using LSD procedure at $5 \%$ level of significance.

\section{Results and Discussion}

Moreover, yield parameters (Table 3) viz., number of panicles $\mathrm{m}^{-2}$ significantly influenced by crop establishment method ZT$\mathrm{DSR}+\mathrm{AR}$ in comparison with PTR (279.25, 277.25 vs $239.50,233.25)$ during the both years respectively, followed by ZT-DSR, RTDSR. 
Table.1 Mean standard monthly meteorological data recorded at Meteorological Observatory, IAS, Varanasi (35 years mean)

\begin{tabular}{|c|c|c|c|c|c|c|}
\hline \multirow[t]{2}{*}{ Month } & \multirow[t]{2}{*}{ PET (mm) } & \multirow[t]{2}{*}{ Rainfall (mm) } & \multicolumn{2}{|c|}{ Temperature $\left({ }^{\circ} \mathrm{C}\right)$} & \multicolumn{2}{|c|}{ Relative humidity (\%) } \\
\hline & & & Max. & Min. & Max. & Min. \\
\hline January & 25.9 & 63.2 & 23.2 & 09.3 & 80 & 51 \\
\hline February & 18.1 & 88.7 & 26.4 & 11.8 & 68 & 37 \\
\hline March & 12.5 & 149.9 & 33.4 & 17.3 & 47 & 24 \\
\hline April & 05.4 & 188.2 & 38.6 & 22.7 & 36 & 20 \\
\hline May & 14.4 & 229.1 & 41.4 & 26.7 & 44 & 24 \\
\hline June & 86.8 & 185.5 & 39.0 & 28.2 & 59 & 45 \\
\hline July & 293.3 & 127.1 & 33.6 & 26.2 & 82 & 73 \\
\hline August & 336.9 & 113.8 & 32.4 & 25.8 & 85 & 79 \\
\hline September & 227.5 & 118.6 & 32.7 & 25.0 & 82 & 74 \\
\hline October & 49.1 & 120.5 & 32.5 & 20.7 & 73 & 55 \\
\hline November & 07.2 & 80.5 & 28.6 & 13.3 & 67 & 47 \\
\hline December & 04.6 & 60.1 & 24.3 & 09.6 & 76 & 51 \\
\hline Annual & 1081.4 & 1525.2 & 32.2 & 19.7 & 76 & 48 \\
\hline
\end{tabular}

Table.2 Mean initial soil characteristics of experimental sites

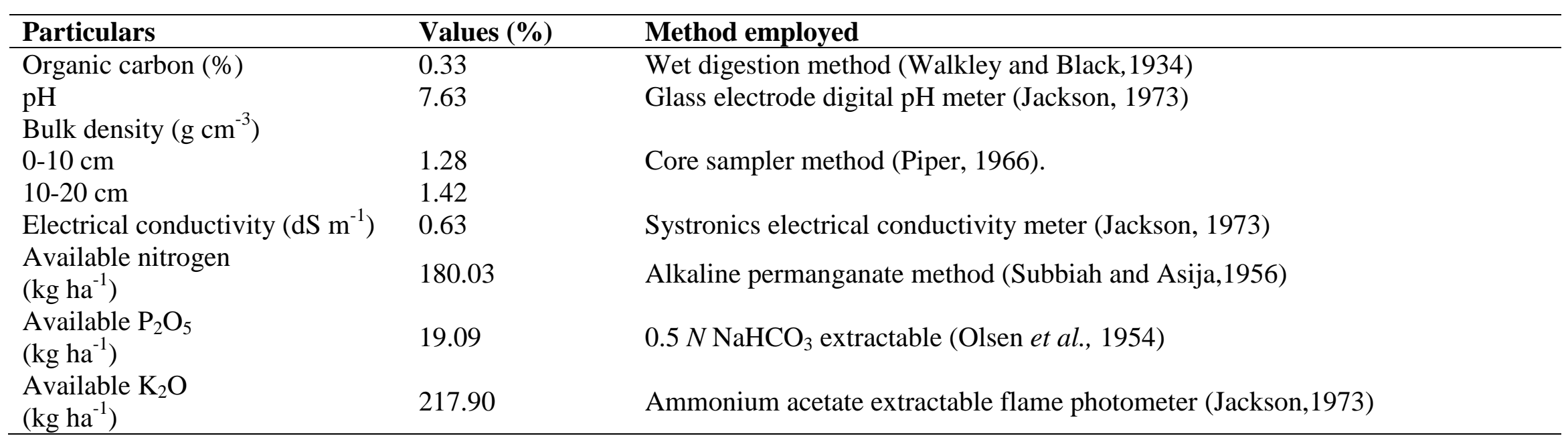


Table.3 Influence of different crop establishment methods on yield attributes of rice

\begin{tabular}{|c|c|c|c|c|c|c|c|c|c|c|}
\hline Treatments & \multicolumn{2}{|c|}{$\begin{array}{c}\text { Panicles } \mathrm{m}^{-2} \\
(\mathrm{No})\end{array}$} & \multicolumn{2}{|c|}{$\begin{array}{c}\text { Panicle length } \\
\text { (cm) }\end{array}$} & \multicolumn{2}{|c|}{$\begin{array}{c}\text { Panicle weight } \\
\text { (g) }\end{array}$} & \multicolumn{2}{|c|}{$\begin{array}{c}\text { Grains Panicle }^{-1} \\
\text { (No) }\end{array}$} & \multicolumn{2}{|c|}{$\begin{array}{c}1000 \text { grains weight } \\
\text { (g) }\end{array}$} \\
\hline \multicolumn{11}{|c|}{ Crop establishment methods } \\
\hline RTDSR & 266.25 & 259.75 & 23.98 & 22.68 & 2.55 & 2.49 & 95.18 & 90.80 & 24.46 & 24.35 \\
\hline ZTDSR & 272.75 & 268.75 & 24.55 & 23.53 & 2.58 & 2.52 & 98.51 & 91.89 & 24.47 & 24.36 \\
\hline SEm \pm & 5.61 & 5.93 & 0.83 & 1.03 & 0.04 & 0.05 & 3.67 & 3.12 & 0.15 & 0.15 \\
\hline $\mathrm{CD}(\mathbf{P}=\mathbf{0 . 0 5})$ & 17.93 & 18.96 & NS & NS & NS & NS & NS & NS & NS & NS \\
\hline
\end{tabular}

Table.4 Influence of different crop establishment methods on yield of rice

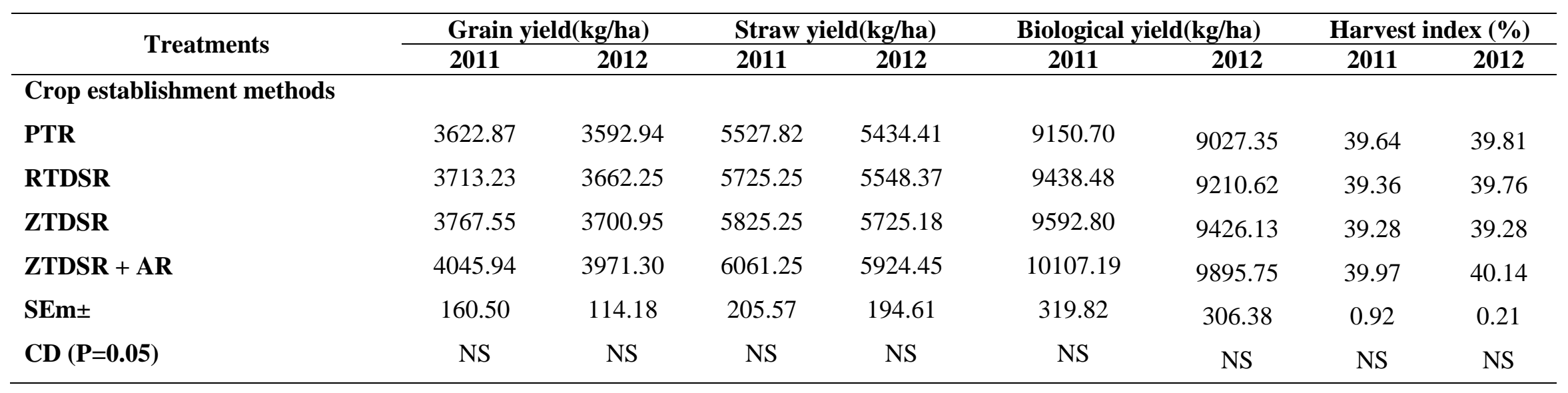


Int.J.Curr.Microbiol.App.Sci (2017) 6(9): 4174-4183

Table.5 Influence of different crop establishment methods on economics of rice

\begin{tabular}{|c|c|c|c|c|c|c|}
\hline \multirow{2}{*}{ Treatments } & \multicolumn{2}{|c|}{ Gross return(₹ /ha) } & \multicolumn{2}{|c|}{ Net return(₹ /ha) } & \multicolumn{2}{|c|}{ B:C ratio } \\
\hline & 2011 & 2012 & 2011 & 2012 & 2011 & 2012 \\
\hline \multicolumn{7}{|l|}{ Crop establishment methods } \\
\hline PTR & 41890.93 & 47628.97 & 14314.03 & 20052.07 & 0.52 & 0.73 \\
\hline RTDSR & 42965.53 & 48552.27 & 18773.63 & 24360.37 & 0.78 & 1.01 \\
\hline ZTDSR & 43602.12 & 49124.47 & 20991.22 & 26513.57 & 0.93 & 1.17 \\
\hline ZTDSR + AR & 46726.80 & 52603.48 & 22615.90 & 28492.58 & 0.94 & 1.18 \\
\hline
\end{tabular}


Whereas, other yield attributes viz. panicle length, panicle weight, grains per panicle and 1000 grain weight were non-significant effected by different crop establishment method. However, higher grain(4045.94, 3971.30 vs $3622.87,3592.94 \mathrm{~kg} / \mathrm{ha}$ ) and straw $(6061.25,5924.45$ vs $5527.82,5434.41 \mathrm{~kg} / \mathrm{ha})$ and biological yield (10107.19, 9895.75 vs 9150.70, $9027.35 \mathrm{~kg} / \mathrm{ha}$ ) was recorded in ZTDSR+AR in comparison to PTR followed by ZT-DSR, RT-DSR in both the years, respectively (Table 4). ZT-DSR + AR were most economical crop establishment method because it gave maximum gross return (Rs 46726.8 and Rs 52603.4), net returns (Rs 22615.90 and (Rs 28492.74) and B: C ratio (0.94 and 1.1) during first and second year, respectively. Whereas, lowest was recorded with puddled transplanted rice (Rs 41890.9 and Rs47628.9), (Rs 14314.03 and Rs 20052.07) which was 36 and $30 \%$ lower than $\mathrm{RE}_{4}$ and (0.52 and 0.73) in 2011 and 2012, respectively (Table 5).Similar or high yield attributes and yield in $\mathrm{ZT}$ rice than conventional rice (CT/PTR) rice were reported earlier by many researchers [Choudhury et al., (2007), Ladha et al., (2009) and Jat et al., (2009) Yadav et al., (2014)].Jat et al., (2014) reported that retention of crop residue in $\mathrm{ZT}$ based production system increase rice and wheat yield over Conventional tilled (CT) based systems.

It may be concluded that rice crop establish through zero-till direct seeded rice under anchored wheat residue $(30 \mathrm{~cm})$ should be followed to achieve higher yield and monitory returns from rice cultivation.

\section{References}

Anonymous, Directorate of Economics and Statistics, Department of Agriculture and Cooperation, Ministery of agriculture and Farmer's welfare. Govt. of India, 2016.

Balasubramanian, V., Hill, JE, Direct seeding of rice in Asia: emerging issues and strategic research needs for 21st century. In: Pandey et al., (Ed.), Direct Seeding: Research Strategies and Opportunities, Proceedings of International Workshop on Direct Seeding in Asian Rice System, January 25-28, Bangkok, Thailand. International Rice Research Institute, Los Banos, Phillippines, pp.15-422002.

Black, C.A., Evans, DD, White, JE, Ensminger, LE and Clark, FE, "Methods of soil analysis", Part IPhysical and Microbiological Properties, Including Statistics of Measurement and Sampling, American Society of Agronomy, pp, 677, 1965.

Chastin, T.G., Ward, JK and Wysocki, DJ, Stand establishment response of soft winter wheat to seed bed residues and seed size.Crop Science.35: 213-218, 1995.

Choudhury, B.U., Bouman, BAM and Singh, AK, Yield and water productivity of rice-wheat on raised beds at New Delhi, India. Field Crops Research, 100: 229239, 2007.

Gomez Kwamchai, A., and Gomez Arturo, A, Statistical procedures for Agricultural Research (2 ${ }^{\text {nd }}$ Ed., 1984), John Wiley and Sons Inc., New York, U.S.A., 1976.

Gupta, R.K., and Sayre, K, Conservation agriculture in South Asia. Journal of Agricultural Sciences Cambridge145: 207-214, 2007.

Guzha, A.C., Effect of tillage on soil microrelief, surface depression storage and soil water storage. Soil \& Tillage Research. 55: 213-218, 2004.

Ho, and Romli, Impact of direct seeding on rice cultivation: lessons from the mudaarea of Malaysia. (In): Proceedings of Workshop on Direct Seeding: Research Strategies and 
Opportunities, held during 25-28 January 2000, Bangkok, Thailand 2000.

Hobbs, P.R., Morris, M, Meeting South Asia's future food requirements from rice - wheat cropping systems: priority issues facing researchers in the PostGreen Revolution era. NRG Paper, pp. 96-1011996.

Jackson, M.L., Soil Chemical Analysis, Prentice Hall of India Pvt. Ltd., New Delhi, pp, 1-492, 1973.

Jat, M.L., Gathala, MK, Ladha, JK, Saharawat, YS, Jat, AS, Kumar, V and Gupta, R, Evaluation of precision land leveling and double zero-till systems in the rice-wheat rotation: Water use, productivity, profitability and soil physical properties. Soil and Tillage Research, 105(1): 112-121, 2009.

Jat, R.K., Sapkota, TB, Singh, RG, Jat, ML, Kumar, M and Gupta, RK, Seven years of conservation agriculture in a ricewheat rotation of Eastern Gangetic Plains of South Asia: Yield trends and economic profitability. Field Crops Research, 164, 199-2102014.

Ladha, J.K., Kumar, V, Alam, MM, Sharma, S, Gathala, M, Chandana, P, Saharawat, YS and Balasubramanian, V, Integrating crop and resource management technologies for enhanced productivity, profitability, and sustainability of the rice-wheat system in South Asia. In: Ladha, J.K., Singh, Y., Erenstein, O., Hardy, B. (Eds.), Integrated Crop and Resource Management in the Rice-Wheat System of South Asia. International Rice Research Institute, Los Bãnos, Philippines, pp. 69-108, 2009.

Olsen, S.R., Cole, CV, Watanabe, FS and Dean, LA, Estimation of available phosphorus in soil by extraction with sodium bicarbonate, U.S. Department of Agriculture Circular, 939, 19-23, 1954.

Piper, C.S., Soil and Plant Analysis, Hans
Publishers, Bombay, 1966.

Saharawat, Y.S., Singh, B, Malik, RK, Ladha, JK, Gathala, M, Jat, ML and Kumar, V, Evaluation of alternative tillage and crop establishment methods in a ricewheat rotation in North Western IGP. Field Crop Research, 116: 260-267, 2010.

Sharma, P.C., Jat, HS, Kumar, V, Gathala, MK, Datta, A, Yaduvanshi, NPS, Choudhary, M, Sharma, S, Singh, LK, Saharawat, Y, Yadav, AK, Parwal, A, Sharma, DK, Singh, G, Jat, ML, Ladha, JK and and McDonald, A Sustainable Intensification Opportunities under Current and Future Cereal Systems of North-West India. Technical Bulletin: CSSRI/Karnal/2015/4. Central Soil Salinity Research Institute, Karnal. p.46, 2015.

Sharma, P.K., Ladha, JK, Bhushan, L, Soil physical effects of puddling in ricewheat cropping systems. In: Ladha et al., (Ed.), Improving the Productivity and Sustainability of Rice-Wheat Systems: Issues and Impacts. ASA Spec. Publ.65: American Society of Agronomy, Crop Science Society of America, and Soil Science Society of America, Madison, WI, pp. 971132003.

Singh, S.N., Sah, AK, Om Prakash Singh, RK, Singh, VK, Assessing the impact of zero tilled wheat growing in rice (Oryza sativa L.)-wheat (Triticumaestivum L.) cropping systems the case of central Uttar Pradesh in the Indo-Gangetic Plain. Outlook on Agriculture. 39 (3): 197-202, 2010.

Singh, U.P., Singh, Y, Kumar Virendra and Ladha, JK, Evaluation and promotion of resource conserving tillage and crop establishment technique in rice-wheat system of eastern India. (In): Ladha JK., Singh Yadvinder, Erenstein O,Hardy B, (Eds.),Integrated crop and resource 
management in rice-wheat system of south Asia. International Rice Research Institute, Los Banos (Philippines), P 151-176, 2009.

Tripathi, R.P., Gaur, MK, Rawat, MS, Puddling effect on soil physical properties and rice performance under shallow water table condition of tarai. Journal of Indian Society of Soil Science 51, 118-124, 2003.

Triplett, G., and Vand Dorren, DR, Agricultural without tillage. Scientific American.236: 28-33, 1977.

Walkley, A., Black, CA, An examination of the method for determination of soil organic matter and proposed medication at the chromic acid titration method, Soil Sci. 37, 29-38,1934.

Yadav, A., Bir, D, Gill, G, Malik, RK, Kamboj, BR, Kumar, V, Jat, RK and Singh, A, Non-puddled direct seeded and mechanical transplanted rice sequentially with no-till wheat to sustain higher productivity and profitability in rice-wheat cropping system in India, In: Proceedings of Biennial conference of Indian Society of weed science on "emerging challenges in weed management", Feburauary15-17, DWSR, Jabalpur, Madhya Pradesh, p. 186, 2014.

\section{How to cite this article:}

Sutaliya J. M., and Singh, U.P.. 2017. Effect of Different Crop Establishment Methods, Tillage and Residue on Yield, Yield Attributes and Economics of Ricein RW System of Northern Plains of IGP. Int.J.Curr.Microbiol.App.Sci. 6(7): 4174-4183.

doi: https://doi.org/10.20546/ijcmas.2017.607.432 